\title{
PENGGUNAAN PEDOMAN OPERASIONAL ALAT PERAGA PENENTUAN LUAS DAERAH LAYANG LAYANG DAN LUAS DAERAH LINGKARAN BAGI SISWA SEKOLAH DASAR
}

\section{OPERATIONAL GUIDELINES FOR THE DETERMINATION OF THE AREA OF THE KITES AND THE CIRCLE AREA FOR ELEMENTARY SCHOOL STUDENTS}

\author{
Ketut Sarjana*, Amrullah, Ratih Ayu Apsari, dan Junaidi \\ Program Studi Pendidikan Matematika FKIP, Universitas Mataram, Mataram, Indonesia \\ *Email: ksarjana@unram.ac.id
}

Diterima: 2 April 2021. Disetujui: 22 Mei 2021. Dipublikasikan: 15 Juni 2021

\begin{abstract}
Abstrak: Tujuan penelitian ini untuk mengetahui bagaimana penggunaan pedoman operasional alat peraga penentuan luas daerah Layang-layang dan luas daerah lingkaran untuk siswa sekolah dasar di Kota Mataram. Alat peraga dan pedoman operasionalnya telah dihasilkan melalui penelitian, untuk melihat penggunaan pedoman operasional tersebut dilakukan implementasi di kelas pada pembelajaran geometri mengenai luas daerah Layanglayang dan lingkaran untuk siswa kelas VI SD di Kota Mataram. Pada saat implementasi telah terjadi suasana pandemi COVID 19. Sampel dari penelitian ini adalah siswa SD kelas VI yang ada di Kota Mataram yang tersebar di 9 kelas yakni di wilayah Ampenan 3 kelas, di Mataram 3 kelas dan di Cakranegara sebayak 3 kelas. Kelaskelas ini dipilih karena telah siap melaksanakan pembelajaran dalam jaringan dan kelas-kelas di setiap wilayah homogen dari segi tempat yang sangat mudah terjangkau dan kemampuan siswa yang hampir sama. Hasil evaluasi menunjukkan bahwa skor rata-rata yang diperoleh dari pasangan tiga kelas di setiap wilayah tidak berbeda secara sigifikan pada taraf signifikansi $5 \%$. Untuk di wilayan Cakranegara, Wilayan Mataram dan di wilayah Ampenan diperoleh $t_{\text {hitung }}<t_{\text {tabel }}=2,002$. Disisi lain ketuntasan yang diperoleh siswa di setiap kelas di setiap wilayah $>$ $80 \%$. Ini berarti bahwa siswa tuntas dalam belajar tentang luas daerah layang-layang dan lingkaran dengan KKM = 70 untuk siswa-siswa di wilayan Mataram dan Ampenan dan KKM sebesar 68 di Wilayah Cakranegara. Disisi lain pesan yang disampaikan sama karena nilai rata-rata yang diperoleh siswa setiap kelas untuk masing-masing wilayah tidak berbeda secara signifikan. Dengan demikian penggunan pedoman operasional alat peraga penentuan luas daerah Layang-layang dan luas daerah lingkaran untuk siswa sekolah dasar di Kota Mataram konsisten dan efekitif.
\end{abstract}

Kata Kunci: Alat peraga, Pedoman operasional, konsistensi, luas daerah layang-layang dan lingkaran.

\begin{abstract}
This study aimed to find out how to use the operational guidelines for determining the area of the kite and the area of the circle for elementary school students in the city of Mataram. The visual aids and operational guidelines have been produced through research, to see the use of these operational guidelines, they are implemented in class in geometry learning about the area of kites and circles for sixth grade elementary school students in Mataram City. At the time of implementation, there was an atmosphere of the COVID-19 pandemic. The sample of this study was grade VI elementary school students in Mataram City who were spread out in 9 classes, namely in the Ampenan area 3 classes, in Mataram 3 classes and in Cakranegara as many as 3 classes. These classes were chosen because they are ready to carry out online learning and the classes in each area are homogeneous in terms of places that are very easily accessible and students' abilities are almost the same. The results of the evaluation showed that the mean scores obtained from the pairs of three classes in each region did not differ significantly at the 5\% significance level. For the Cakranegara, Mataram and Ampenan areas, we get tcount $<$ ttable $=2.002$. On the other hand, the completeness obtained by students in each class in each region is $>80 \%$. This means that students are complete in learning about the area of kites and circles with a KKM $=70$ for students in the Mataram and Ampenan areas and a KKM of 68 in the Cakranegara region. On the other hand, the message conveyed is the same because the average score obtained by students in each class for each region is not significantly different. Thus, the use of operational guidelines for determining the area of the kite and the area of the circle for elementary school students in Mataram City is consistent and effective.
\end{abstract}

Keywords: Props, operational guidelines, consistency, kite and circle area.

\section{PENDAHULUAN}

Sulitnya siswa sekolah dasar belajar geometri, karena materi geometri sangat abstrak sedangkan siswa sekolah dasar cara berpikirnya masih pada taraf operasi kongkret. Hal ini sejalan dengan apa yang diungkap oleh Piaget dalam Hudoyo menyebut bahwa siswa sekolah dasar berpikirnya masih pada taraf operasi kongkret [1]. Berkenaan dengan hal ini jika siswa sekolah dasar belajar geometri sebaiknya dihadapkan dengan obyek atau benda yang kongkrit yang cocok, benda dimanipulasi oleh anak untuk membangun konsep atau prinsip geometri yang sedang dipelajari. Hal ini sesuai dengan pernyataannya Brunner dalam 
Nyimas Aisyah menyebut bahwa dalam proses belajar anak sebaiknya diberi kesempatan memanipulasi benda-benda yang dirancang secara khusus dan dapat diotak atik oleh siswa di dalam memahami konsep matematika [2].

Siswa belajar memanfaatkan alat peraga akan banyak berbuat. Pandangan ini cocok dengan motto yang dikutip oleh Ruseffendi yang mengatakan bahwa Saya dengar maka saya lupa, Saya lihat maka saya tahu, Saya berbuat maka saya mengerti [3]. Disisi lain juga dikemukakan oleh Brunner menyebut bahwa dalam tahap enaktif siswa secara langsung terlibat dalam memanipulasi obyek. Dari keteraturan obyek yang diamati siswa dapat mengabstraksi konsep dan prinsip yang dipelajari. Hal ini sesuai dengan pandangan kontruktivis adalah suatu pandangan yang menyatakan bahwa didalam belajar dan mengajar dimana peserta didik harus membangun sendiri arti dari pengalamannya dan interaksi dengan orang lain. Inilah sebagai alasan mengapa pengajaran matematika khususnya pengajaran geometri di SD memerlukan media peraga dan bantu. Dengan media ini siswa merasa senang, termotivasi, tertarik dan bersikap positif terhadap pengajaran matematika.

Sudah banyak tulisan yang menyebut bahwa penggunaan alat peraga dalam pembelajaran matematika menyebabkan pempelajaran menjadi efektif. Salah satu yang diungkap oleh Brown (1970) dalam Asra [4] menyebut bahwa media yang digunakan siswa atau guru dengan baik dapat mempengaruhi efektifitas proses belajar dan mengajar. Namun pernyataan itu belum menyebut bagaimana tata cara penggunaan media itu dapat dilakukan supaya sampai kepada tujuannya. Menggunakan alat peraga menentukan luas daerah jajaran genjang dan segitiga hasilnya berbeda satu dengan yang lainnya walaupun alat peraga yang digunakan sama untuk materi yang sama dan pada tingkatan yang sama. Ini berarti bahwa guru membutuhkan instrumen lain supaya pesan yang disampaikan sama. Itulah sebabnya diperlukan suatu petunjuk penggunaan alat peraga. Masalahnya sekarang adalah "Bagaimana Penggunaan pedoman operasional alat peraga untuk menentukan luas daerah layang-layang dan daerah lingkaran bagi siswa SD di Kota Mataram ?

Tujuan penelitian ini untuk mengetahui konsistensi dan efektifitas dari implementasi petunjuk penggunaan alat peraga menetukan luas daerah Layang-layang dan luas daerah lingkaran bagi siswa sekolah dasar di Kota Mataram.

Pemilihan muatan materi pelajaran yang tepat, yaitu yang dapat dipahami berdasarkan pengalaman kongkret siswa, maka alat peraga menjanjikan sebagai media dan sumber pembelajaran yang cocok bagi siswa SD. Melalui alat siswa dapat melihat secara langsung keteraturan yang ada, sehingga siswa lebih berhasil dalam belajarnya. Disisi lain melalui alat peraga siswa belajar melalui berbuat dan aktif belajar baik perorangan maupun berkelompok, karena alat peraga yang digunakan dapat dimanipulasikan dengan cara dikutak-katik seperti diraba, dipegang, dipindahkan atau dipasang dan dibongkar. Agar pemanfaatan alat peraga ini menjadi optimal, maka dalam mengoperasikannya diperlukan petunjuk penggunaannya. Menyangkut hal ini telah dilakukan penelitian tentang kontruksi alat peraga dan pedoman opersionalnya. Oleh Ketut Sarjana dkk [5]. Hasil penelitian menyebutkan bahwa alat yang dikontruksi sangat valid. Jadi dapat dipahami bahwa siswa belajar dapat efektif bergantung pada sarana yang digunakan. Hal ini sejalan dengan Sudjana [6] prestasi belajar yang dicapai siswa dipengaruhi oleh faktor eksternal. Begitu pula Slameto [7] prestasi belajar dipengaruhi oleh pemanfaatan media pembelajaran.

Setiap konsep abstrak dalam matematika yang baru dipahami anak perlu segera diberikan penguatan supaya mengendap, melekat dan tahan lama tertanam sehingga menjadi miliknya dalam pola pikir maupun pola tindaknya. Untuk keperluan inilah, maka diperlukan belajar melalui berbuat dan pengertian, tidak hanya sekedar hapalan atau mengingat-ingat fakta saja yang tentunya mudah dilupakan dan sulit untuk dapat dimiliki. Pandangan ini cocok dengan motto yang dikutip oleh Ruseffendi yang mengatakan bahwa saya dengar maka saya lupa, saya lihat maka saya tahu, saya buat maka saya mengerti [8-9]

Slogan saya lihat maka saya tahu mengisyaratkan kepada pendidik bahwa pada setiap proses pembelajaran matematika diharapkan memanfaatkan media yang dapat dilihat. Karena dengan cara melihat konsep abstrak geometri dapat dipahami dengan mudah. Selanjutnya saya berbuat dan saya mengerti membawa inspirasi bahwa di dalam kegiatan proses belajar matematika diharapkan siswa harus berbuat. Melalui cara berbuat siswa akan merasakan apa yang dipelajari bermakna bagi dirinya. Hal ini akan menjadi tenaga penggerak bagi siswa untuk mencari tahu tentang apa yang sedang dipelajari. Untuk itu media peraga yang digunakan untuk memperlancar proses sedianya yang berupa barang yang dapat dimanipulasikan yaitu dikutak-katik seperti diraba, dipegang, dipindahkan atau dibongkar pasang. Disisi lain alat bantu yang dimaksud adalah petunjuk penggunaan alat peraga alat peraga. Petunjuk penggunaan alat berfungsi menjelaskan cara melakukan bagaimana alat dapat digunakan yang para pemakainya belum seragam memahami. Inilah sebagai alasan mengapa pengajaran matematika khususnya pengajaran geometri di SD memerlukan alat peraga.

Dalam suatu pembelajaran keterampilan atau pengetahuan tertentu, strategi modelling adalah upaya untuk memberikan atau menyediakan model yang bisa ditiru sebelum siswa berlatih sendiri 
secara mandiri. Menurut Bandura, belajar yang dialami siswa adalah sebagian besar diperoleh dari suatu pemodelan, yaitu meniru perilaku dan pengalaman orang lain [10]. Model yang dimaksud biasanya berupa cara mengoperasikan sesuatu atau memberi contoh cara mengerjakan sesuatu, dan secara umum bagaimana cara mempelajari materi tertentu. Menyinggung pernyataan ini supaya alat peraga dapat digunakan dengan cara yang sama oleh setiap pemakainya pada topik yang sama diperlukan petunjuk penggunaan.

\section{METODE PENELITIAN}

Dalam penelitian ini menerapkan alat bantu pembelajaran seperti alat peraga geometri tentang menentukan luas daerah Jajaran genjang, daerah segitiga, lengkap dengan pedoman operasional di kelas bagi siswa SD di kelas kelas VI. Untuk mempermudah guru menggunakan media tersebut dibuatkan petunjuk penggunaannya.

Alat peraga dan petunjuk penggunaanya telah dibuat yang merupakan hasil penelitian yang dilakukan pada tahun 2018 Oleh Ketut Sarjana dkk. Hasil penelitian menunjukkan bahwa alat yang dikontruksi dan petunjuk penggunaannya telah layak dan valid. Kelayakan alat tersebut divalidasi oleh 9 orang yang terdiri dari 3 orang ahli dan 6 orang praktisi.

Sebagai populasi pada penelitian ini adalah siswa kelas VI dan SD Negeri yang ada di Kota Mataram. Sampel diambil menggunakan teknik sampling purposive. Teknik ini digunakan karena penelitian dilakukan di masa pandemi COVOI 19 dimana pembelajaran menggunakan pembelajaran dalam jaringan. Para guru SD di kota Mataram pemahaman tentang aplikasi pembelajaran jarak jauh tidak seragam dan lebih banyak menggunakan WhatsApp. Untuk itu diwakili oleh para siswa SD kelas VI sebanyak 9 kelas. Siswa SD ini tersebar di Cakranegara sebanyak 3 kelas, di Mataram 3 kelas dan di Ampenan 3 kelas. Kelas kelas ini homogen dari segi skor rata-rata dan berada di wilayah sangat strategis. Disamping itu telah dilakukan wawancara bahwa di kelas-kelas ini siswa mengembalikan pekerjaan kepada gurunya hampir $100 \%$ tepat waktu.

Dalam melaksanakan pembelajaran para guru dibantu dengan mendisain alat peraga tentang menentukan luas daerah bangun jajaran genjang dan segitiga dalam bentuk vedio pembelajaran. Mengenai pedoman operasaional dari alat peraga dinarasikan dalam vedio dan disesuaikan dengan petunjuk penggunaan alat peraga yang telah disusun.

Untuk memperoleh data tentang kepastian petunjuk penggunaan alat muncul dalam pembelajaran digunakan alat observasi. Uraian alat ini meliputi menggali prasyarat pengetahuan, menunjukkan unsur unsur dari bangun yang akan dicari luas daerahnya, melakukan percobaan memotong dan merangkai dan mencari hubungan unsur-unsur bangun datar untuk meyimpulakan rumus luas daerah yang dicarai. Tes digunakan untuk memeperoleh data tentang prestasi belajar siswa mengenai luas daerah jajaran genjang dan segitiga.

Teknik analisis data yang digunakan dalam penelitian adalah teknik deskriptip yaitu mencocokan pedoman opersional dengan narasi pada vedio dengan menggunakan sekala tidak tepat, kurang tepat dan tepat sangat tepat. Selanjutnya data mengenai hasil tes dianalis menggunakan uji $\boldsymbol{t}$ [11] dua arah karena sampel yang dibedakan terbatas dan taraf sigifikasi 0,05 . Selanjutnya untuk mengetahui efektifitas pembelajaran menggunakan vedio digunakan uji ketuntasan yakni siswa dikatakan tuntas jika $80 \%$ lebih dari seluruh siswa memperoleh skor minimal sama dengan nilai ketuntantasan minimal (KKM).

\section{HASIL DAN PEMBAHASAN}

Sebelum implementasi dilaksanakan, dilakukan pemutaran vedio. Pemutaran vedio dimaksudkan untuk mencari imformasi tentang kecocokan antara narasi yang ada pada vedio dengan butir-butir dari pedoman opersional. Observasi vedio dilakukan oleh 9 guru SD senior yang masingmasing 3 guru dari 3 wilayah Cakranegara, Mataram dan Ampenen.

Data dari hasi observasi dari 9 guru SD setelah diolah menunjukkan bahwa petunjuk penggunaan alat peraga sangat tepat setelah dinarasikan di dalam vedio pembelajaran. Disisi lain data yang diperoleh dari hasil tes kemampuan siswa tentang luas daerah jajaran genjang dan luas daerah segitiga terlihat pada table 1 .

Belajar matematika berarti belajar tentang fakta, konsep prinsip dan operasi. Fakta meyangkut tentang postulat atau aksioma, konsep menyangkut tentang pengertian seperti definisi dan prinsip menyangkut tentang teorema, sifat, dalil ataupun rumus. Barang matematika ini adalah hal yang abstrak. Hal ini sesuai dengan apa yang diungkap oleh Hudoyo seperti pada uraian sebelumnya.

Dipahami bahwa siswa sekolah dasar berada pada taraf berpikir kongkrit. Sehingga jika pengajaran geometri seperti prinsip luas Jajaran genjang dan segitiga dipaksakan apa adanya jelas akan bermasalah. Akibatnya pengajaran matematika pada usia ini mengharuskan untuk memanfaatkan perantara, yang meyebabkan geometri dapat berkomunikasi dengan siswa sekolah dasar. Perantara disini adalah sebuah alat peraga yang di desain sedemikian rupa sehingga siswa dapat mengamati, meraba dan mencoba, menemukan selanjutnya menalar dalam rangka membangun prinsip-prinsip geometri. Prinsip geometri dalam penelitian ini menyangkut tentang rumus luas daerah daerah jajaran genjang dan luasdaerah segitiga. Alat peraga yang digunakan guru yang berbeda di dalam mempercepat proses pembelajaran dengan topik 
sama, belum tentu pesan yang disampaikan sama. Sehingga media peraga perlu didampingi dengan petunjuk penggunaan untuk menepis pernyataan tadi.

Tabel 1. Output uji-t independen di kelas-kelas di wilayah Cakranegara

\begin{tabular}{|c|c|c|c|c|c|}
\hline & $A 2$ & $B 2$ & & $A 2$ & $C 2$ \\
\hline Mean & 77,76667 & 75,18333 & Mean & 77,76667 & 76,63333 \\
\hline Variance & 113,8402 & 39,74971 & Variance & 113,8402 & 72,03333 \\
\hline Observations & 30 & 30 & Observations & 30 & 30 \\
\hline df & 58 & & $\mathrm{df}$ & 58 & \\
\hline t Stat & 1,14172 & & t Stat & 0,455312 & \\
\hline t Critical two-tail & 2,001717 & & t Critical two-tail & 2,001717 & \\
\hline
\end{tabular}

\begin{tabular}{lrr}
\hline & \multicolumn{1}{c}{$B 2$} & \multicolumn{1}{c}{$C 2$} \\
\hline & & 76,6333 \\
Mean & 75,18333 & 3 \\
& & 72,0333 \\
Variance & 39,74971 & 3 \\
Observations & 30 & 30 \\
df & 58 & \\
t Stat & $\mathbf{- 0 , 7 5 1 1 7}$ & \\
t Critical two-tail & 2,001717 & \\
\hline
\end{tabular}

Tabel 2. Rekap nilai t-hitung SD di wilayah Cakranegara

\begin{tabular}{ccc}
\hline Group & t-hitung & t-tabel \\
\hline A2 - B2 & 1,1417 & \\
A2 - C2 & 0,4553 & 2,002 \\
B2 - C2 & $-0,7512$ & \\
\hline
\end{tabular}

Tabel 3. Output uji - $\mathrm{t}$ independen di kelas-kelas di wilayah Mataram

\begin{tabular}{|c|c|c|c|c|c|c|}
\hline \multirow[b]{2}{*}{ Mean } & $A 2$ & \multirow{2}{*}{$\begin{array}{c}B 2 \\
77,58333\end{array}$} & \multicolumn{3}{|r|}{$A 2$} & \multirow{2}{*}{$\frac{C 2}{80,09375}$} \\
\hline & 78,03226 & & \multicolumn{2}{|l|}{ Mean } & 78,03226 & \\
\hline Variance & 125,0489 & 105,6049 & \multicolumn{2}{|l|}{ Variance } & 125,0489 & 185,7006 \\
\hline Observations & \multicolumn{2}{|c|}{31} & \multicolumn{2}{|c|}{ Observations } & 31 & 32 \\
\hline df & \multicolumn{2}{|c|}{59} & \multicolumn{2}{|c|}{$\mathrm{df}$} & 61 & \\
\hline t Stat & 0,163108 & & t Stat & & $-0,65521$ & \\
\hline \multirow[t]{7}{*}{ t Critical two tail } & \multirow{2}{*}{\multicolumn{2}{|c|}{2,000995}} & \multicolumn{2}{|c|}{$\mathrm{t}$ Critical two-tail } & 1,999624 & \\
\hline & & & $B 2$ & $C 2$ & & \\
\hline & \multicolumn{2}{|c|}{ Mean } & 77,58333 & \multicolumn{2}{|c|}{80,09375} & \\
\hline & \multicolumn{2}{|c|}{ Variance } & 105,6049 & \multicolumn{2}{|c|}{185,7006} & \\
\hline & \multicolumn{2}{|c|}{ Observations } & 30 & \multicolumn{2}{|c|}{32} & \\
\hline & \multicolumn{2}{|c|}{ df } & 60 & & & \\
\hline & \multicolumn{2}{|c|}{$\begin{array}{l}\text { t Stat } \\
\text { t Critical two-tail }\end{array}$} & $\begin{array}{r}-0,81479 \\
2,000298 \\
\end{array}$ & & & \\
\hline
\end{tabular}


Tabel 4. Rekap nilai t-hitung untuk SD di wilayah Mataram

\begin{tabular}{ccc}
\hline Group & t-hitung & t-tabel \\
\hline A2 - B2 & 0,1631 & \\
A2 - C2 & $-0,6552$ & 2,000 \\
B2 - C2 & $-0,8148$ & \\
\hline
\end{tabular}

Tabel 5. Output uji-t independen di kelas-kelas di wilayah Ampenan

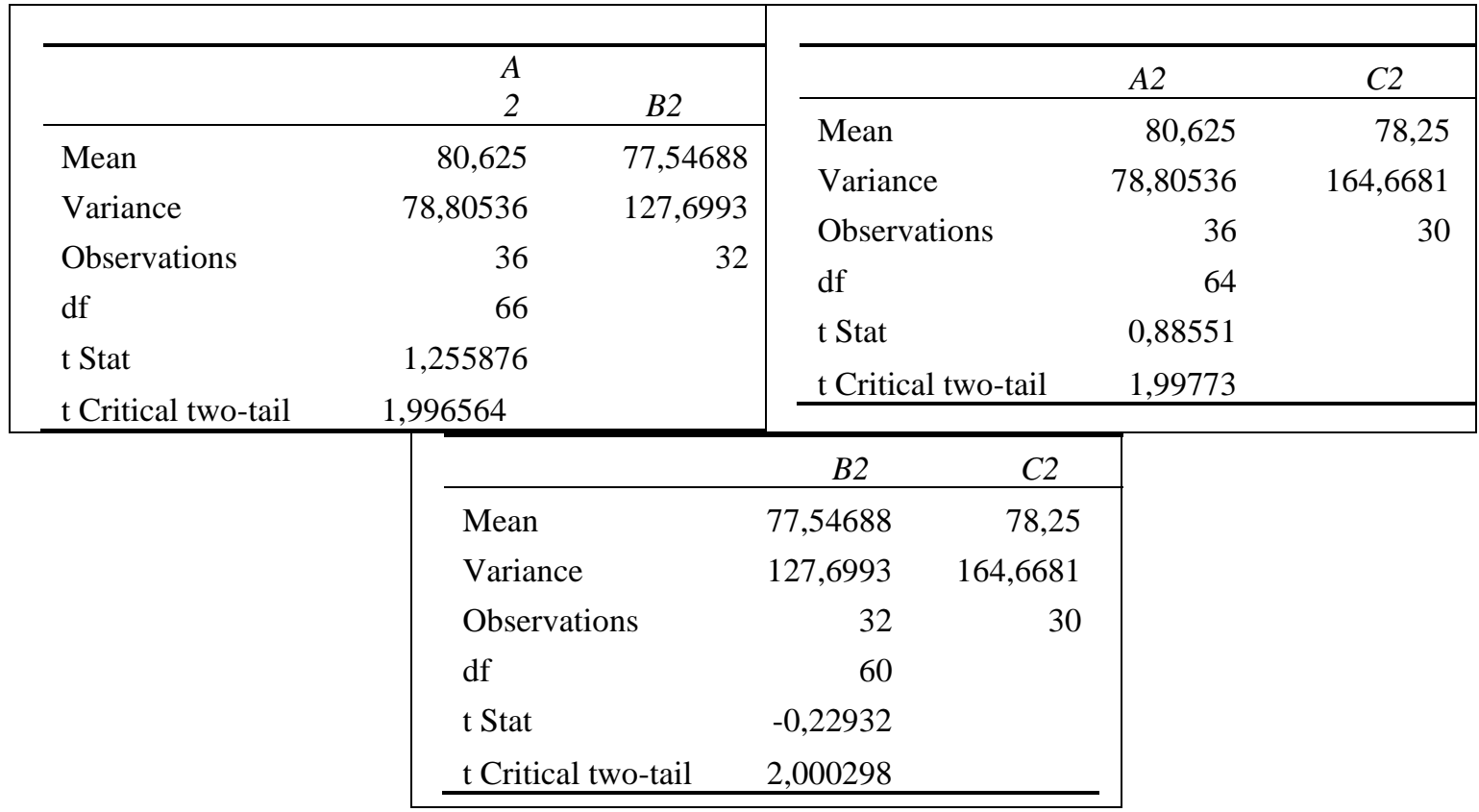

Tabel 6. Rekap nilai t-hitung SD di wilayah Ampenan.

\begin{tabular}{ccc}
\hline Group & t-hitung & t-tabel \\
\hline A2 - B2 & 1,2559 & \\
A2 - C2 & 0,8855 & 2,000 \\
B2 - C2 & $-0,2293$ & \\
\hline
\end{tabular}

Uji Hipotesis :

$>\mathrm{H}_{0}: \mu_{\text {kelas }_{i}}=\mu_{\text {kelas }_{j}}$

$\mathrm{H}_{\mathrm{a}}: \mu_{\text {kelas }_{i}} \neq \mu_{\text {kelas }_{j}}$

$>$ Jika $-\mathrm{t}_{\text {tabel }}<\mathrm{t}_{\text {hitung }}<\mathrm{t}_{\text {tabel }}$ maka $H_{0}$ tidak ditolak,

$>$ Karena $-\mathrm{t}_{\text {tabel }}<\mathrm{t}_{\text {hitung }}<\mathrm{t}_{\text {tabel }}$ maka $\mu_{\text {kelas }_{i}}=\mu_{\text {kelas }_{j}}$ yang berarti bahwa mean nilai siswa SDN di Wilayah Cakranegara, Mataram dan Ampenan yaitun kelas A2, B2 dan C2 dengan diberikan perlakuan X adalah sama.

Pada penelitian ini mengimplentasikan alat peraga geometri untuk siswa sekolah dasar kelas tinggi yakni siswa SD kelas VI dilengkapi dengan petunjuk penggunaannya. Di atas telah diuraikan bahwa implementasi penelitian pada saat pandemic COVID 19 sehingga pilihan memodifikasi alat dengan vedio pembelajaran adalah pilihan yang paling jitu

Implementasi alat peraga melalui vedio dilakukan oleh para guru dengan beberapa langkah seperti membagikan vedio, kemudian para siswa mengamati, mengerjakan tugas, klarifikasi dari guru, menyelesaikan latihan yang disetting dalam lembar kerja siswa, dan yang terakhir dilakukan tes. Dari hasil implementasi telah diperoleh hasil analisis data bahwa untuk siswa SD di wilayah Cakra Negara diperoleh harga $\left|t_{h}\right|<t_{\text {tabel }}=2,002$, di wilayah Mataram harga $\left|t_{h}\right|<t_{\text {tabel }}=2,00$ dan siswa SD di wilayah Ampenan diperoleh $\left|t_{h}\right|<t_{\text {tabel }}=2,00$. Ini berarti bahwa pasangan kelompok nilai yang diperoleh siswa di tiap-tiap wilayah baik di Cakranegara, Mataram maupun Ampenan skor rataratanya tidak berbeda secara signifikan pada taraf signifiknasi 0,05. Ini berarti bahwa tidak ada perbedaan yang berarti prestasi belajar antara siswa di tiap wilayah. Jadi dengan menggunakan petunjuk 
penggunaan alat peraga tentang menentukan luas daerah Layang-layang dan luas daerah lingkaran pesan yang disampaikan sama sehingga alat yang digunakan menjadi konsisten.

Disamping itu penggunaan alat peraga membuat pembelajaran efektif karena telah diperoleh ketuntasan belajar diatas $80 \%$. Hal ini bermakna bahwa $80 \%$ lebih dari seluruh siswa memperoleh skor minimal sama dengan KKM. Untuk Cakranegara KKM $=68$, untuk Mataram $\mathrm{KKM}=70$ dan Ampenan memiliki $\mathrm{KKM}=70$. Kuantitas ini mejelaskan bahwa telah terjadi perubahan prestasi belajar yang lebih baik. Ini berarti pembelajaran menjadi efektif. Hal ini sesuai yang disebut oleh Brown (1970) dalam Asra menyebut bahwa media yang digunakan siswa atau guru dengan baik dapat mempengaruhi efektifitas proses belajar dan mengajar.

Dari hasil tersebut menujukkan bahwa siswa belajar melalui alat peraga konsep abstrak bisa diamati oleh siswa melalui tayangan. Disisi lain melalui perintah yang ada siswa dapat berbuat melakukan kegiatan mencoba, tidak sekedar mengingat.

Penggunaan alat peraga dalam pembelajaran menyebabkan pempelajaran menjadi efektif. Media yang digunakan siswa atau guru dengan baik dapat mempengaruhi efektifitas proses belajar dan mengajar [12-14]. Jadi hal ini sesuai dengan motto yang dikutif Ruseffendi yang menyatakan bahwa saya dengar maka saya lupa, saya lihat maka saya tahu, saya berbuat maka saya mengerti.

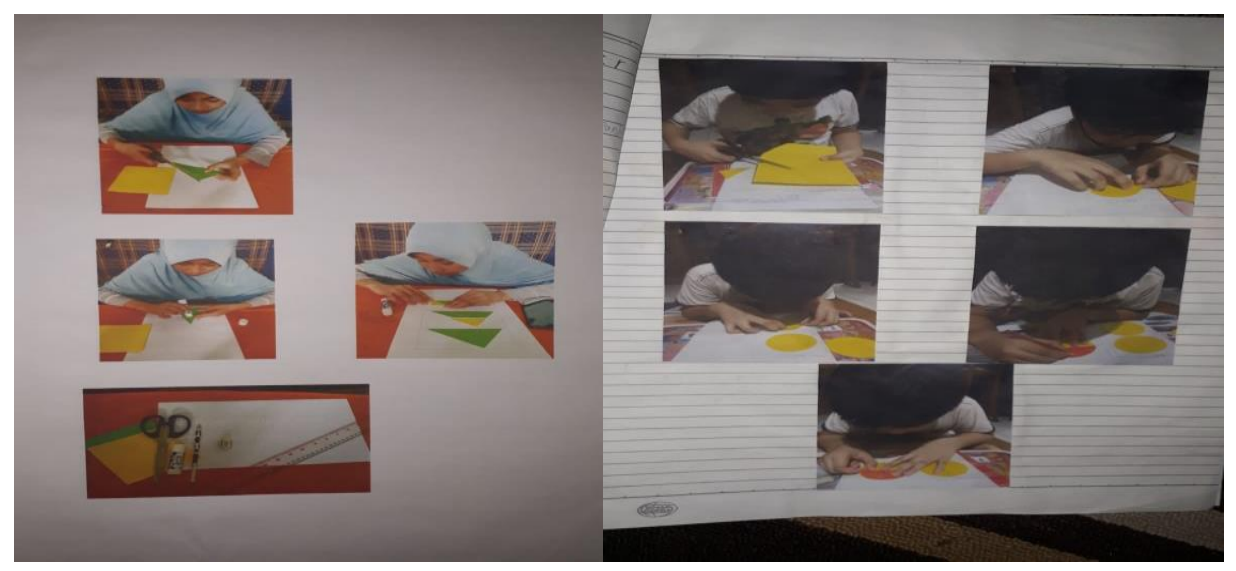

Gambar 1. Foto siswa melakukan kegiatan, memotong, mewarnai dan merankai

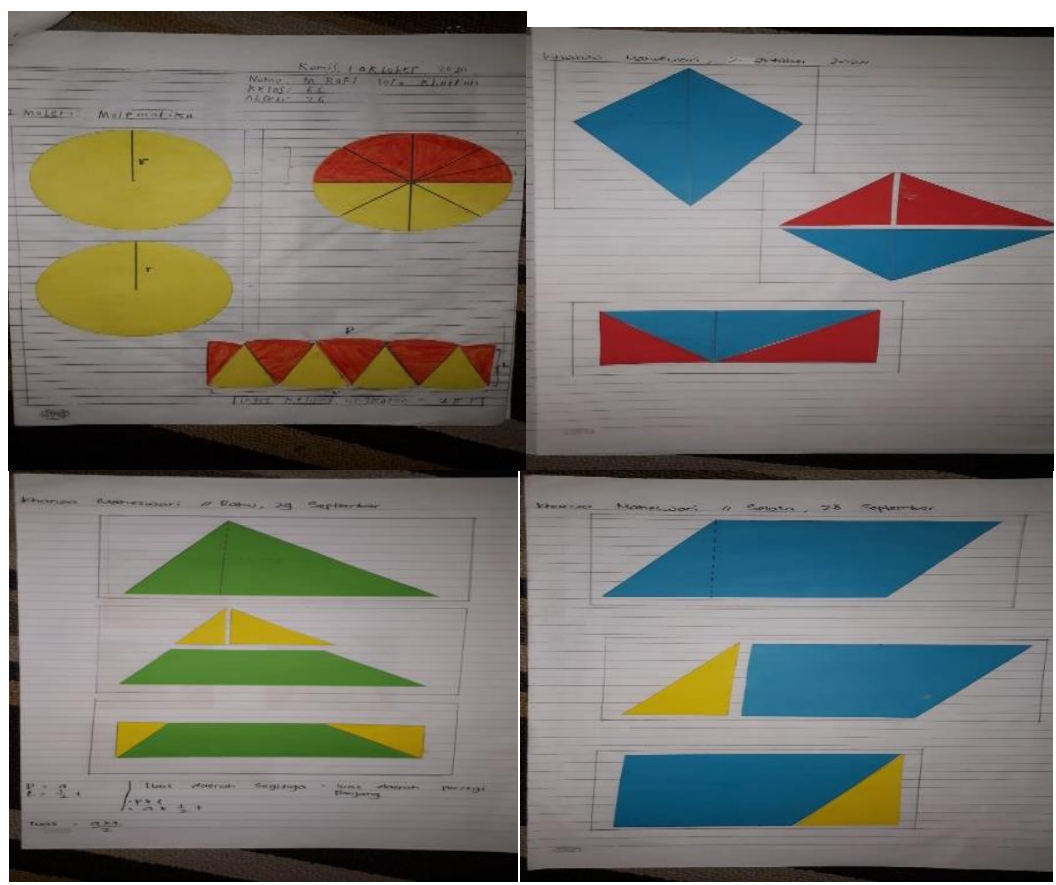

Gambar 2. Foto hasil melakukan percobaan: memotong, mewarnai dan merangkai 
Slogan saya lihat maka saya tahu mengisyaratkan bahwa pada setiap proses pembelajaran matematika diharapkan memanfaatkan media yang dapat dilihat. Karena dengan cara melihat konsep abstrak geometri dapat dipahami dengan mudah. Selanjutnya saya berbuat dan saya mengerti membawa inspirasi bahwa di dalam kegiatan proses belajar matematika diharapkan siswa harus berbuat. Melalui cara berbuat siswa akan merasakan apa yang dipelajari bermakna bagi dirinya. Hal ini akan menjadi tenaga penggerak bagi siswa untuk mencari tahu tentang apa yang sedang dipelajari. Disisi lain alat peraga dengan petunjuk operasional, peman- faatannya lebih optimal, karena petunjuk penggunaan alat itu berfungsi menjelaskan cara melakukan bagaimana alat dapat digunakan oleh para pemakainya yang belum seragam memahaminya.

Jadi secara keseluruhan penggunaan alat peraga yang dilengakapi dengan petunjuk penggunaannya menyebabkan pembelajaran menentukan rumus luas daerah layang-layang dan luas daerah lingkaran menjadi konsiten dan efektif.

\section{KESIMPULAN}

Hasil penelitian menyimpulkan bahwa melalui penerapan alat peraga dalam pembelajaran mementukan rumus luas daerah jajaran genjang dan luas daerah segitiga menjadi efektif. Hal ini dapat diketahui dari ketuntasan yang dicapai untuk setiap kelas di Kota Mataram lebih dari $80 \%$. Dengan memnfaatkan petunjuk penggunaan alat pembelajaran menjadi konsisten karena telah diperoleh uji dua perbedaan nilai rata-rata tidak berbeda secara signifikan. Hal ini dapat diketahui $\left|t_{\text {hitung }}\right|<t_{\text {tabel }}=2,002$. Jadi dengan menggunakan alat peraga dilengkapi petunjuk penggunaannya pembelajaran menjadi konsisten dan efektif.

\section{UCAPAN TERIMA KASIH}

Ucapan terima kasih disampaikan kepada Bapak Rektor, Bapak Ketua LPPM Universitas Mataram, Bapak Dekan FKIP Universitas Mataram yang telah meberikan dukungan pendanaan PNBP DIPA BLU UNRAM tahun Anggaran 2020 dengan Kontrak perjanjian No.2622/UN18.L1/PP/2020. Tak lupa pula disampaikan terima kasih kepada Tim sehingga laporan penelitian ini dapat diselesaikan.

\section{DAFTAR PUSTAKA}

[1] Hudoyo, H. (1997). Pengembangan Kurikulum Matematika di depan Kelas. Usaha Nasional. Surabaya.
[2] Aisyah, N, dkk. (2007). Pengembangan Pembelajaran Matematika SD. Jakarta: Departemen Pendidikan Nasional.

[3] Russefendi, E.T. (1996). Pendidikan Matematika III Modul 1-9, Depdikbud, Proyek Tenaga Kependidikan Jakarta.

[4] Asra, A., Darmawan, D., Riana, C. (2007). Komputer dan Media Pembelajaran di SD. Dirjen Dikti Departemen Pendidikan Nasioanal. Jakarta.

[5] Sarjana, K., Sridana, N., \& Turmuzi, M. (2019). Disain Media Peraga Dan Bantu Pembelajaran Geometri Bagi Siswa Sekolah Dasar Kelas Tinggi. Jurnal Ilmiah Profesi pendidikan, 3(2), 298770.

[6] Sudjana, N. (1992). Dasar-Dasar Proses Belajar Mengajar. Bandung. Rosda Karya.

[7] Slameto, S. (2003). Belajar dan Faktor-Faktor yang Mempengaruhinya. Jakarta. Renika Cipta.

[8] Slamet, S., \& Maarif, S. (2014). Pengaruh bentuk tes formatif assosiasi pilihan ganda dengan reward dan punishment score pada pembelajaran matematika siswa SMA. Infinity Journal, 3(1), 59-80.

[9] Helmi, J. (2016). Penerapan Konsep Silberman dalam Metode Ceramah Pada Pembelajaran PAI. Al-Ishlah: Jurnal Pendidikan, 8(2), 221245.

[10]Nur, M. (2011). Modul keterampilanketerampilan proses sains. Surabaya: Pusat Sains dan Matematika Sekolah Universitas Negeri Surabaya.

[11]Dayan, A. (1990). Metode Statistik. Lembaga Penelitian dan Penerangan ekonomi dan social, Jln. S Parman. Jakarta Barat.

[12] Usmiatiningsih, E., Harjono, A., \& Jufri, A. W. (2013). Efektivitas Multimedia Interaktif Berbasis Flash Dan Model 5e Untuk Meningkatkan Sikap Terhadap Sains Siswa SMP Negeri 6 Mataram. Jurnal Pijar Mipa, 8(1).

[13] Al-idrus, S. Q. M. J., Hikmawati, H., \& Wahyudi, W. (2015). Pengaruh model pembelajaran berbasis masalah berbantuan video kartun terhadap hasil belajar fisika siswa kelas xi sman 1 sikur tahun ajaran 2014/2015. Jurnal Pijar MIPA, 10(1).

[14] Susilawati, S., Jamaluddin, J., \& Bachtiar, I. (2017). Pengaruh model pembelajaran berbasis masalah (PBM) berbantuan multimedia terhadap kemampuan berpikir kritis peserta didik kelas vii smp negeri 2 mataram ditinjau dari kemampuan akademik. Jurnal Pijar Mipa, 12(2), 64-70. 